\begin{tabular}{|c|c|c|}
\hline 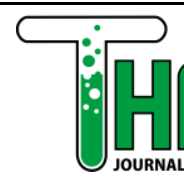 & [URAL SCIENCE TEACHING & $\begin{array}{l}\text { Thabiea : Journal of Natural Science Teaching } \\
\text { Vol. 3(2), pp. 131-140, } 2020 \\
\text { Available online at } \\
\text { http://journal.iainkudus.ac.id/index.php/Thabiea } \\
\text { p-issn: } 2580-8474 \text {, e-issn: } 2655-898 X\end{array}$ \\
\hline
\end{tabular}

\title{
Scaffolding in Learning Cycle 5E, is it Effective or Not?
}

\author{
Vidya Setyaningrum ${ }^{1 *}$, Rody Putra Sartika ${ }^{2}$ \\ IAIN Pontianak, Jl Letjend Soeprato No 09, Pontianak, 78121, Indonesia \\ *Correspondence: vidyasetyaningrum@iainptk.ac.id
}

\begin{tabular}{ll}
\hline & Abstract \\
\hline Keywords: & Learning chemistry in the chemistry education study program has not maximized the \\
Effectiveness & scaffolding provision yet, so students still have difficulty in mastering the precondition \\
Learning cycle 5E & concept. This study aims to determine the effectiveness of learning using the 5E \\
Scaffolding & learning cycle modelassisted by scaffolding on acid and base materialas seen from an \\
& increase in students' understanding of concepts. This research is a quasi-experiment \\
& with one group pretest-posttest design. The subjects of this study were 32 students who \\
& choose randomly from the chemical education study program class of 2019. The \\
& instrument used is an essay learning achievement test to measure students' \\
& understanding of acid and base concepts. The results showed that the n-gain value \\
& obtained is 0.31 or can be interpreted as an increase with moderate criteria. Therefore \\
& it can be concluded that the addition of scaffolding in the 5E learning cycle is effective \\
& to increase students' understanding on acid and base material.
\end{tabular}

To cite this article:

Setyaningrum, V., Sartika, R. P., (2020). Scaffolding in Learning Cycle 5E, is it Effective or Not?. Thabiea : Journal of Natural Science Teaching, 3(2), 131-140.

\section{Introduction}

Chemistry lessons are still a scourge for students because there are many difficult materials in them. One of the material is acid-base, Acid-base matter consists of from concepts that are concrete, abstract, and chemical calculations (Sem et al., 2019). From the results of the preliminary studies to students of the Chemistry Education program at Teacher training program of FKIP UNTAN as follows: 1) Students assume that ionized term same as hydrolyzed; 2) Students assume that the strong or weak nature of an acid or base depends on the strength of conducting electric current; 3) Students cannot distinguish between strong or weak acids and strong or weak bases; and 4) Students are wrong in determining the $\mathrm{pH}$ of the solution.

The results above indicate that errors that occur in students are caused by not understanding the basic concepts in acid-base material. For example in distinguishing the nature of strong or weak acids and strong or weak bases, students must first understand the concepts of ionization and equilibrium, while in determining the $\mathrm{pH}$ of the solution students must first understand the concepts of moles and concentrations. If students do not underst and the prerequisite concept properly, they will experience difficulties in understanding the next concepts.

Students need to repeat the prerequisite materials they have learned, so they can understand the concepts being studied in their entirety. According to Nur'aini (2009; in Lubis $\&$ Simatupang, 2014) the more students repeat a lesson, the greater the learning retention they get. Repetition of concepts that have been studied previously can be done through the 
provision of scaffolding. Scaffolding is giving the student a large amount of assistance during the initial stages of learning and then reduce the assistance and provide an opportunity for the students to take over greater responsibility as soon as they can do it themself (Katminingsih, 2009). The scaffolding technique described as change in level of support during the learning process takes place. Scaffolding will be provided if needed and will be reduced along with increased student knowledge (Rusli et al., 2017).

Anghileri, (2006) states that there is three levels of scaffolding. In the first level, before cooperating with their students teacers platform learning with natural arrangements including curios (for instance, decision of divider shows, manipulatives, puzzles, fitting apparatuses) and homeroom association, including guest plans as well as sequencing and pacing functions. At the next level explaining, reviewing and restructuring involve direct interactions between teacher and students related specifically to the mathematics being considered. Highest level of scaffolding consists of teaching interactions that explicitly addresses developing conceptual thinking by creating opportunities to reveal understandings to pupils and teachers together. At this highest level, teachers in the classroom can engage their pupils in conceptual discourse that extends their thinking. The establishment of representational tools is located centrally as it is most commonly found where teachers notate mathematical processes. Less commonly found, but identified as the most effective interactions, are those specifically focused on making connections and generating conceptual discourse.

Based on the results of interviews with chemistry lecturers in 2018, it was found that in learning $2^{\text {nd }}$ basic chemistry course was still delivered only by the lecturing method, also question and answer method. Such learning still does not maximize the provision of scaffolding, so mastery of the concept of prerequisites by students is still low. Learning devices on acid-base material used by lecturers in basic chemistry II courses still tend to place students as recipients of information without trying to construct information independently. Besides that, the provision of scaffolding in the available textbooks is still minimal, so that students have not been able to master the prerequisite concepts well.

Juniarsih \& Chamisijatin (2015) states that good learning is actually not just an activity that only transfers knowledge from educators to students, but an activity that allows students to be able to build their own knowledge, for example by making meaning and seeking clarity. Such learning can be realized with a constructivist approach, where one of them can use the 5E learning cycle model. The 5E learning cycle model consists of five learning phases which include: Engagement, Exploration, Explanation, Elaboration, and Evaluation (Lorsbach, 2002). According to Duran et al., (2011) the learning cycle is a research-based learning model that can help students explore concepts in science and help educators plan meaningful learning and deep understanding of concepts. Research conducted by Balci et al., (2006) shows that the use of the learning cycle can clarify the thought process and improve students' misconceptions. In addition, research conducted by Sartika \& Lestari, (2016) obtained that the 5E learning cycle model can improve students' understanding of concepts and critical thinking.

This study aims to determine the effectiveness of learning using the 5E learning cycle model assisted by scaffolding in acid-base material as seen from an increase in students' understanding of concepts. Belland, et al (in Setyarini et al., 2107) states that one kind of 
scaffolding is hard scaffolding which can be obtained in hard form like textbook or students worksheet. The scaffolding in this study is done in the exploration and elaboration phase through textbooks and students' worksheets that can help students find and construct the concepts and apply them in new situations.

\section{Method}

This section is used both for the articles derived from research and study results. The research method contains the technique in data collection, the analysis used to obtain the results, also the number of respondents used in the study. Formula writing can use the equation including the main source as a reference. The literature research must contain a flow of thought in the study, steps in data collection (information gathering), analytical techniques, and standards of reference used to conduct a critical and in-depth study.

This research is a quasi-experimental design with one group pretest-posttest design. The subjects of this study were 32 students who choose randomly from the chemical education study program class of 2019 consisting of 3 classes.

(Baroh, 2010) stated that the effectiveness of education is often measured by the achievement of goals or accuracy in managing a situation because effectiveness emphasizes the comparison between plans and goals to be achieved. So in this study, the effectiveness of scaffolding in the learning cycle $5 \mathrm{E}$ was measured by comparing student achievement before and after the learning process. The data collection technique used is the measurement technique, and the instrument used is a learning achievement test to measure students' understanding of concepts.

Improved understanding of the concept is carried out in a descriptive qualitative analysis with the following steps: a) Scoring answers on student learning outcomes tests b) Calculate the increase in understanding of student concepts with the normalized gain formula according to Hake in Nissen et al (2018) as follows:

Information:

$$
\mathrm{g}=\frac{\left(\bar{x}_{\text {post }}-\bar{x}_{\text {pre }}\right)}{100 \%-\bar{x}_{\text {pre }}}
$$

$\mathrm{g} \quad=$ Average normalized gain.

$\bar{x}_{\text {post }}=$ Average class posttest.

$\bar{x}_{\text {pre }}=$ Average class pretest.

The criteria for obtaining a normalized gain score are classified into three levels in Table 1.

Table 1. Classification of gain normalization

\begin{tabular}{cc}
\hline Normalized gain score & Calssification \\
\hline $\mathrm{g}<0,3$ & Low \\
\hline $0,3 \leq \mathrm{g}<0,7$ & Moderate \\
\hline $\mathrm{g} \geq 0,7$ & High \\
\hline
\end{tabular}




\section{Results and Discussion}

The effectiveness of scaffolding in learning by using the 5E learning cycle model can be known from the improvement of student learning outcomes before and after treatment is given. The improvement of student learning outcomes can be seen in Table 2. The average increase in student learning outcomes after being given a scaffolding-assisted learning cycle $5 \mathrm{E}$ learning model using learning tools developed at 0.31 with moderate criteria. This is in line with Rahmatiah et al., (2016) who found that scaffolding can improve students achievement. Handoko \& Winarno, (2019) in their research also found that addition of scaffolding in teachers learning media, can improve students achievement.

Table 2. Increased understanding of student concepts.

\begin{tabular}{ccccc}
\hline & Pre-test & Post-test & & \\
Code & Score & Score & N-Gain & Criteria of Improvement \\
& & & & \\
\hline UL1 & 33,33 & 71,72 & 0,58 & Moderate \\
\hline UL2 & 37,37 & 70,71 & 0,53 & Moderate \\
\hline UL3 & 9,09 & 69,70 & 0,67 & Moderate \\
\hline UL4 & 45,45 & 68,69 & 0,43 & Moderate \\
\hline UL5 & 40,40 & 66,67 & 0,44 & Moderate \\
\hline UL6 & 30,30 & 53,54 & 0,33 & Moderate \\
\hline UL7 & 12,12 & 50,51 & 0,44 & Moderate \\
\hline UL8 & 16,16 & 47,47 & 0,37 & Moderate \\
\hline UL9 & 25,25 & 43,43 & 0,24 & Low \\
\hline UL10 & 19,19 & 43,43 & 0,30 & Moderate \\
\hline UL11 & 13,13 & 39,39 & 0,30 & Moderate \\
\hline UL12 & 29,29 & 38,38 & 0,13 & Low \\
\hline UL13 & 11,11 & 38,38 & 0,31 & Moderate \\
\hline UL14 & 20,20 & 30,30 & 0,13 & Low \\
\hline UL15 & 15,15 & 25,25 & 0,12 & Low \\
\hline UL16 & 13,13 & 24,24 & 0,13 & Low \\
\hline UL17 & 0,00 & 20,20 & 0,20 & Low \\
\hline UL18 & 53,54 & 73,74 & 0,43 & Moderate \\
\hline UL19 & 54,55 & 68,69 & 0,31 & Moderate \\
\hline UL20 & 41,41 & 66,67 & 0,43 & Moderate \\
\hline UL21 & 50,51 & 64,65 & 0,29 & Low \\
\hline UL22 & 28,28 & 58,59 & 0,42 & Moderate \\
\hline UL23 & 38,38 & 54,55 & 0,26 & Low \\
\hline UL24 & 30,30 & 52,53 & 0,32 & Moderate \\
\hline UL25 & 27,27 & 47,47 & 0,28 & Low \\
\hline UL26 & 23,23 & 46,97 & 0,31 & Moderate \\
\hline UL27 & 28,28 & 46,46 & 0,25 & Low \\
\hline & & & & Low \\
\hline UL28 & 18,18 & 40,40 & 0,27 & \\
\hline & & & \\
\hline & & & \\
\hline
\end{tabular}




\begin{tabular}{ccccc}
\hline & \multicolumn{2}{c}{ Pre-test } & Post-test & \\
\cline { 3 - 4 } Code & Score & Score & N-Gain & Criteria of Improvement \\
& & & & \\
\hline UL29 & 13,13 & 35,86 & 0,26 & Low \\
\hline UL30 & 9,09 & 31,31 & 0,24 & Low \\
\hline UL31 & 17,17 & 29,80 & 0,15 & Low \\
\hline UL32 & 9,09 & 24,24 & 0,17 & Low \\
\hline \multicolumn{2}{c}{ Average } & $\mathbf{4 8 , 2 5}$ & $\mathbf{0 , 3 1}$ & Moderate \\
\hline
\end{tabular}

The 5E learning cycle model provides an opportunity for students to independently find and construct information through five learning phases including; engagement, exploration, explanation, elaboration, and evaluation. The scaffolding of this model is done in the exploration and elaboration phase through textbooks and students' worksheets that can help students find and construct the concepts and apply them in new situations. According to Sari et al (2016), the use of teaching materials for independent learning is one way to find out the potential for students' independent learning. Student learning potential can be seen from the understanding of the concepts they obtained after using textbooks and students' worksheets in the $5 \mathrm{E}$ learning cycle model independently.

The learning cycle model is carried out in five learning phases consisting of; engagement, exploration, explanation, elaboration, and evaluation. The $5 \mathrm{E}$ learning cycle model in this study can assist students in finding and constructing the concept of the colligative nature of solutions through practical activities. The process of discovery and conceptual construction is carried out at each learning phase of the 5E learning cycle model. In the engagement phase, the students' initial knowledge is explored by asking questions on the previous material (solution material), where the material is related to the colligative nature of the solution to be studied. Lecturers explore students' knowledge by giving apperception at the beginning of learning. According to Mulyasa (2011) to make a connection with learning, educators can do it by linking the material to be delivered with material that has been mastered by students. The activity is carried out to get the attention of students in learning, encourage thinking skills, and help them make connections with prior knowledge and experience. Student misconceptions about the prerequisite material can be identified at this phase, to reduce cognitive imbalances that occur.

Besides apperception, in the engagement phase students are also given motivation by asking questions related to phenomena in everyday life on acid-base material. According to Kiswoyowati (2011) as an effort to improve the life skills of students, it is necessary to increase the motivation and learning activities of students. Furthermore, the lecturer communicates the learning objectives that must be achieved by students, this is done so that they make preparations to achieve these learning goals. According to Sukmadinata (2010), one of the benefits of learning objectives is that it is easy to communicate the intent of teaching and learning activities to students so that students can do their learning more independently. Students can prepare learning materials independently in support of the discovery and construction of the concept of acid-base, because they have been informed beforehand about what they hope to achieve. 
The second phase of the 5E learning cycle is exploration, where students construct concepts independently through practicum activities. According to Rahmawati et al (2016), concept construction can occur because students gain knowledge through scientific activities. Scientific activities carried out in the exploration phase encourage students to always find out in finding and / or proving a concept. Students are formed in heterogeneous groups of 5-6 people. The use of study groups with mixed abilities to enhance concept change (Slavin, 2011). Heterogeneous groups are formed to increase student confidence through collaboration to help each other understand the concepts being learned. According to Astutik (2012), the 5E learning cycle can arouse students' enthusiasm in learning and increase collaboration between students and become more confident.

Students are given a students' worksheet (LKM 1) and textbooks related to acid-base material, where each student gets one students' worksheet. LKM 1 and textbooks provide an opportunity for students to independently construct the acid-base concept with the help of scaffolding and be actively involved in practicum activities by observing and exploring concepts related to the results of observations to achieve the expected goals following learning indicators. This is in line with Gusmardin et al., (2019) who states that scaffolding can help students in constructing their knowledge. The aims of scaffolding is to help students who experience difficulties in learning (Badriyah et al., 2017). The provision of scaffolding can help students understand the concepts learned in their entirety. Concepts or information just learned will be constructed by students through the process of accommodation to achieve cognitive equilibrium.

According to Oktafiani (2019) learning with the 5E learning cycle model is based on inqury. Investigation during the learning process can facilitate students to acquire scientific knowledge through reasoning based on the evidence obtained. Tuna \& Ahmet (2013) also states that the $5 \mathrm{E}$ model targets discoveries and associations with prior knowledge by students relating to new concepts. During the activity in this phase, students are asked to do a practicum and answer every question in LKM 1. Concept formation is a form of discovery learning, at least in primitive form, which involves psychological processes such as discriminatory analysis, abstraction, differentiation, the formation of (generation) hypothesis, testing, and generalization. Guidance is given when students begin to find and construct an explanation of the phenomena given in LKM 1. Guidance is given in the form of questions that lead students to find and form the concept of acid-base. Asking probing question is an excellent way to scaffold students' learning and help them to develop more sophisticated thinking skills (Santrock, 2011).

In the explanation phase, group representatives are asked to present LKM 1 which was discussed in the previous phase. The group of students who made the presentation were allowed to show the understanding and skills they had constructed during the exploration phase, while the other students responded. The concepts that have been constructed by students will be clarified whether they are following the concepts of the experts. If it still contradicts or is not under the concept of the experts, it will be completed and refined, so it is hoped that misconceptions will not appear again in the next phase. According to Utami et al (2013) students are allowed to express concepts that have been built by their experiences, while students who do not understand the material are required to dare to ask questions so there is a discussion between the students' presentations with other students in the class. 
Students present the results of the practicum that has been obtained in the exploration phase in front of the class, where the groups that make presentations are drawn.

After the explanation phase continues with the elaboration phase, wherein this phase students conduct further practicum to develop the knowledge that has been obtained in the previous phases in the new situation. In this phase, students use advanced students' worksheet with new phenomena that can develop the acid-base concept they have discovered before (exploration phase). This situation can be realized by carrying out new research activities or by expanding activities carried out at the exploration stage (Rahmawati et al., 2016). According to Ibrahim (2012) the mastery of the concept well, broadly, and deeply as possessed by experts in certain scientific fields, enables a person or the expert concerned to apply his mastery in various purposes. In this phase, students are allowed to apply the concept of acid and base that has been found and constructed in the previous phase in different situations so that the mastery of concepts gained is more extensive and in-depth. According to Wilder \& Shuttleworth (2010) activities provide additional motivation for students to apply their knowled ge correctly in the elaboration phase.

The last phase of the $5 \mathrm{E}$ learning cycle model is the evaluation by giving students a learning outcome test to find out how far they understand the acid-base material and the expected learning objectives. According to Utami et al., (2013) at the evaluation stage two things want to be known in learning activities, namely 1) the learning experience gained by students and,2) reflection to carry out further cycles for learning in the next concept. Students use the knowledge they have gained in completing tests of learning outcomes independently.

The learning cycle model can arouse students' interest in the material to be learned through the engagement phase, where educators are expected to make the learning atmosphere less tense so that students become enthusiastic and their curiosity increases. Also, educators are expected to be able to convince students that the material being studied is important and useful for them. It is important to convince students about the important level of attractiveness of the material to be presented, to show (if possible) how the knowledge that will be obtained will benefit him (Bergin, 1999).

The learning cycle model can also maintain student curiosity through the exploration phase and the elaboration phase. In that phase, the educator divides students into several heterogeneous groups and provides worksheets to each group containing the tasks used to guide students in finding concepts to learn and provide direct experience to students. According to Guthrie and Cox (Slavin, 2011) found that giving direct experience to natural science activities to students greatly improved their learning from books on related topics and provided more motivation.

\section{Conclusion}

From the data and discussion above, it can be concluded that the addition of scaffolding in the learning cycle $5 \mathrm{E}$ is effective in increasing students' understanding of concepts by 0.31 with moderate criteria.

Further study should allocate more time and conduct intensive guidance, especially in the elaboration phase. Because in this phase students are still confused about applying and developing the concepts they learn. 


\section{References}

Anghileri, J. (2006). Scaffolding practices that enhance mathematics learning. Journal of Mathematics Teacher Education, 9(1), 33-52. https://doi.org/10.1007/s10857-0069005-9

Astutik, S. (2012). Meningkatkan Hasil Belajar Siswa dengan Model Siklus Belajar (Learning Cycle 5E) Berbasis Eksperimen pada Pembeljaran Sains di SDN Patrang 1 Jember. Jurnal Ilmu Pendidikan Sekolah Dasar, 1(2), 143-153.

Badriyah, L., As'ari, A. R., \& Susanto, H. (2017). ANALISIS KESALAHAN DAN SCAFFOLDING SISWA BERKEMAMPUAN RENDAH DALAM MENYELESAIKAN OPERASI TAMBAH DAN KURANG BILANGAN BULAT. Jurnal Pendidikan: Teori, Penelitian, dan Pengembangan, 2(1), 50-57.

Balci, S., Cakiroglu, J., \& Tekkaya, C. (2006). Engagement, exploration, explanation, extension, and evaluation (5E) learning cycle and conceptual change text as learning tools. Biochemistry and Molecular Biology Education, 34(3), 199-203. https://doi.org/10.1002/bmb.2006.49403403199

Baroh, C. (2010). Efektivitas metode Simulasi dalam pembelajaran Matematika pada pokok bahasan Peluang di Kelas IX-A MTs Nurul Huda Kalanganyar Sedati Sidoarjo. UIN Sunan Ampel Surabaya.

Bergin, D. A. (1999). Influences on classroom interest. Educational Psychologist, 34(2), 8798. https://doi.org/10.1207/s15326985ep3402_2

Duran, E., Duran, L., Haney, J., \& Scheuermann, A. (2011). A Learning Cycle for All Students. The Science Teacher, 5.

Gusmardin, Y., Bektiarso, S., \& Wicaksono, I. (2019). PENGARUH MODEL PEMBELAJARAN GUIDED INQUIRY DISERTAI SCAFFOLDING PROMPTING QUESTIONING TERHADAP KETERAMPILAN PROSES SAINS SISWA PADA MATERI GERAK LURUS DI SMA. Jurnal Pembelajaran Fisika, 8(2), 93-100.

Handoko, H., \& Winarno. (2019). Pengembangan Perangkat Pembelajaran Matematika melalui Pendekatan Scaffolding Berbasis Karakter. Jurnal Pendidikan Matematika, 8, 12.

Ibrahim, M. (2012). Konsep, Miskonsepsi dan Cara Pembelajarannya. Unesa University Press.

Juniarsih, Q. A., \& Chamisijatin, L. (2015). PENINGKATAN RETENSI BELAJAR MATERI KLASIFIKASI MAKHLUK HIDUP MELALUI PENERAPAN DISCOVERY LEARNING DAN TEAM GAMES TOURNAMENT PADA SISWA KELAS VII-G SMP NEGERI 18 MALANG. Prosiding Seminar Nasional Pendidikan Biologi 2005, 157-167.

Katminingsih, Y. (2009). Vygotsky dan Teorinya dalam Mempengaruhi Desain Pembelajaran Matematika. STKIP PGRI Blitar.

Kiswoyowati, A. (2011). PENGARUH MOTIVASI BELAJAR DAN KEGIATAN BELAJAR SISWA TERHADAP KECAKAPAN HIDUP SISWA. Portal Jurnal Universitas Pendidikan Indonesia, 2(1), 12-16.

Lorsbach, A. W. (2002). The Learning Cycle as a Tool for Planning Science Instruction. http://www.coe.ilstu.edu/scienceed/lorsbach/257lrcy.htm 
Lubis, N. F., \& Simatupang, Z. (2014). PENINGKATAN DAYA RETENSI SISWA TERHADAP KONSEP- KONSEPBIOLOGI MELALUIPEMANFAATAN MEDIA ADOBE FLASH PADA MODEL PEMBELAJARAN LANGSUNG. Prosiding Seminar Nasional Biologi Dan Pembelajarannya, 654-664.

Mulyasa. (2011). Menjadi Guru Profesional Menciptakan Pembelajaran Kreatif dan Menyenangkan. Remaja Rosdakarya.

Nissen, J. M., Talbot, R. M., Nasim Thompson, A., \& Van Dusen, B. (2018). Comparison of normalized gain and Cohen's d for analyzing gains on concept inventories. Physical Review Physics Education Research, 14(1), 010115. https://doi.org/10.1103/PhysRevPhysEducRes.14.010115

Oktafiani, A. R. (2019). Efektivitas Model Pembelajaran Siklus 5E Terhadap Kemampuan Berpikir Tingkat Tinggi pada Materi Virus Siswa SMA Negeri 16 Semarang. Universitas Islam Negeri Walisongo.

Rahmatiah, R., Handayanto, S. K., \& Kusairi, S. (2016). Pengaruh Scaffolding Konseptual dalam Pembelajaran Group Investigation Terhadap Prestasi Belajar Fisika Siswa SMA dengan Pengetahuan Awal Berbeda. Jurnal Pendidikan Fisika Dan Teknologi, 2(2), $45-54$.

Rahmawati, Supriyono, K. H., \& Dasna, I. W. (2016). Kajian Pengaruh Learning Cycle 5E Terhadap Keterampilan Proses Sains Peserta Didik SMP. Prosiding Seminar Nasional Pendidikan IPA, 1 .

Rusli, M. A., Prabowo, P., \& Widodo, W. (2017). PEMBELAJARAN FISIKA MELALUI PEMROSESAN TOP DOWN BERBASIS SCAFFOLDING UNTUK MELATIHKAN KETERAMPILAN BERPIKIR KRITIS. JPPS (Jurnal Penelitian Pendidikan Sains), 2(1), 164. https://doi.org/10.26740/jpps.v2n1.p164-169

Santrock, J. W. (2011). Educational psychology (5th ed). McGraw-Hill.

Sari, I., Sonjaya, Y., \& Anwar, S. (2016). PENGGUNAAN BAHAN AJAR HASIL TERJEMAHAN UNTUK MENINGKATKAN PEMAHAMAN KONSEP DAN KEMANDIRIAN BELAJAR. EduChemia (Jurnal Kimia dan Pendidikan), 1(1), 3650.

Sartika, R. P., \& Lestari, I. (2016). PENERAPAN MODEL SIKLUS BELAJAR 5E DALAM MENINGKATKAN KETERAMPILAN BERPIKIR KRITIS SISWA KELAS IX SMAN 2 PONTIANAK PADA MATERI KOLOID. Prosiding Seminar Nasional Kimia dan Pembelajarannya, 166-175.

Sem, A., Iskandar, S., \& Rahayu, S. (2019). Pengaruh Model Daur Belajar Enam Fase-STAD Terhadap Hasil dan Motivasi Belajar Siswa pada Materi Asam Basa. EduChemia $\begin{array}{lllll}\text { (Jurnal Kimia dan } & \end{array}$ https://doi.org/10.30870/educhemia.v4i1.1846

Setyarini, D. A., Subiki, \& Supeno. (2107). KEMAMPUAN BERPIKIR KRITIS SISWA DALAM PEMBELAJARAN IPA (FISIKA) SMP DENGAN MENGGUNAKAN LEMBAR KERJA SISWA (LKS) BERBASIS. Seminar Nasional Pendidikan Fisika $2107,2,7$.

Slavin. (2011). Psikologi Pendidikan Teori dan Praktik Edisi Kesembilan. PT Indeks.

Sukmadinata, N. S. (2010). Pengembangan Kurikulum: Teori dan Praktek. PT Remaja Rosdakarya Offset. 
Tuna, A., \& Ahmet, K. (2013). THE EFFECT OF 5E LEARNING CYCLE MODEL IN TEACHING TRIGONOMETRY ON STUDENTS' ACADEMIC ACHIEVEMENT AND THE PERMANENCE OF THEIR KNOWLEDGE. International Journal on New Trends in Education and Their Implications, 4(1), 73-81.

Utami, B., Hastuti, B., Yamtinah, S., \& Padmini, S. (2013). PENERAPAN SIKLUS BELAJAR 5E DISERTAI LKS UNTUK PENINGKATAN KUALITAS PROSES DAN HASIL BELAJAR KIMIA. Cakrawala Pendidikan, XXXII(2), 315-325.

Wilder, M., \& Shuttleworth, P. (2010). Cell Inquiry: A 5e Learning Cycle Lesson. Science Activities: Classroom Projects and Curriculum Ideas, 41(4), 37-43. https://doi.org/10.3200/SATS.41.4.37-43 